\title{
Hubungan pemberian ASI Eksklusif dan Makanan Pendamping ASI terhadap Balita Pendek Usia 2 sampai 5 tahun di Kecamatan Jatinangor
}

\author{
Yogi Subandra Dwitama ${ }^{1}$, Yenni Zuhairini², Julistio Djais ${ }^{3}$ \\ ${ }^{1}$ Fakultas Kedokteran Universitas Padjadjaran \\ ${ }^{2}$ Departemen Ilmu Kesehatan Masyarakat, Fakultas Kedokteran Universitas Padjadjaran \\ ${ }^{3}$ Departemen Ilmu Kesehatan Anak, Fakultas Kedokteran Universitas Padjadjaran/ \\ Rumah Sakit Umum Pusat DR. Hasan Sadikin, Bandung
}

\begin{abstract}
Abstrak
Balita pendek masih menjadi masalah generasi di Indonesia. Balita pendek disebabkan oleh berbagai faktor. Penelitian ini bertujan untuk mengetahui hubungan pemberian ASI eksklusif dan makanan pendamping ASI (MP-ASI) terhadap kejadian balita pendek usia 2 sampai 5 tahun. Penelitian analitik observasional ini dilakukan dengan pendekatan potong lintang. Subjek sebanyak 65 balita usia 2 sampai 5 tahun dengan kriteria inklusi memiliki riwayat berat lahir dan usia kehamilan normal di Kecamatan Jatinangor pada bulan Juni-Agustus 2017. Pengambilan sampel dilakukan dengan sampling acak bertahap. Pengambilan data karakteristik, pemberian ASI, dan MP-ASI dilakukan dengan cara wawancara. Pengukuran status gizi dilakukan berdasarkan TB/U. Analisis statistik yang digunakan adalah uji statistik Chi square dan Fisher. Angka kejadian balita pendek pada penelitian ini sebesar $40 \%$. Pola menyusui ASI parsial memiliki proporsi paling banyak dibandingkan ASI eksklusif. Jenis pemberian MP-ASI umumnya diberikan dari pabrik (usia 6-9 bulan) dan buatan sendiri (usia 9-24 bulan). Pada usia 12 s.d. 24 bulan, seluruh balita diberikan jenis MP-ASI dari buatan sendiri. Hubungan antara pemberian ASI eksklusif dan MP-ASI dengan balita pendek masing-masing $p<0,05$ dan $p>0,05$. Terdapat hubungan antara pemberian ASI eksklusif dan balita pendek, tetapi tidak terdapat hubungan antara MP-ASI dan balita pendek.
\end{abstract}

Kata Kunci : ASI eksklusif, Jatinangor, MP-ASI, pendek

\section{Association between Exclusive Breastfeeding and Complementary Feeding in Stunted Children Aged 2 to 5-years old in Jatinangor Sub-District}

\author{
Abstract
}

Stunted children is still a major generational problem in Indonesia. Stunting is caused by multiple factors. This study aims to find out the association between exclusive breastfeeding and complementary feeding $(C F)$ in stunted children aged 2 to 5-years old. This observational analytic study was conducted using cross-sectional approach. As much as 65 young children aged 2 to 5 years old in Jatinangor sub-district were included as subjects with inclusion criteria being normal birthweight and gestation period on June-August 2017. Data regarding characteristics, breastfeeding, and complementary feeding were obtained through interview. Nutritional status was determined with body height/age. Statistical analysis used were Chi-square and Fisher statistical test. Prevalence of stunted children in this study was $40 \%$. Partial breastfeeding pattern had the most proportion compared to exclusive breastfeeding. Type of complementary food provided was most commonly factorymade (age 6 to 9 months old) and homemade (age 9 to 24 months old). At 12 to 24 months, all children are given homemade complementary food. The association between exclusive breastfeeding and CF with stunting was $p<0.05$ and $p>0.05$ respectively. There is a significant association between exclusive breastfeeding and stunting, however there is no significant relationship between complementary feeding and stunting.

Keywords : Complementary feeding, exclusive breastfeeding, Jatinangor, stunted

\footnotetext{
Korespondensi:

Yogi Subandra Dwitama

Fakultas Kedokteran Universitas Padjadjaran

Jl. Bandung - Sumedang KM. 21 Jatinangor

Mobile : 081319672855

Email : yogi.subandra@gmail.com
} 


\section{Pendahuluan}

Sejumlah 162 juta anak berusia di bawah lima tahun (balita) di dunia adalah balita pendek, mereka mengalami kehilangan potensi ekonomi. Balita pendek menyelesaikan sekolah lebih lama, kemampuan belajar kurang baik, mendapatkan upah yang lebih rendah ketika dewasa, dan terjerat kehidupan kemiskinan apabila dibandingkan dengan balita dengan nutrisi baik. ${ }^{1}$

Pada tahun 2025, Indonesia akan mengalami bonus demografi yaitu ketika rasio penduduk usia non produktif paling rendah. ${ }^{2}$ Negara yang penduduk usia produktif lebih banyak dibandingkan penduduk usia non produktif akan meningkatkan pendapatan per kapita negara. Sebagian penduduk usia produktif pada tahun 2025 merupakan balita yang lahir pada tahun 2010 hingga sekarang. Namun hingga saat ini, permasalahan kesehatan pada balita masih menjadi permasalahan di Indonesia. Apabila permasalahan balita tidak tertangani dengan baik, hal tersebut menyebabkan kesempatan bonus demografi tidak akan didapatkan maksimal.

Balita pendek merupakan salah satu permasalahan kesehatan balita di Indonesia. Menurut WHO, balita pendek akan menjadi masalah kesehatan masyarakat jika prevalensi lebih dari $20 \%$, di Indonesia, prevalensi balita pendek pada tahun 2013 sebesar 37,2\% sehingga masalah ini harus ditanggulangi. Berdasarkan Riset Kesehatan Dasar (RISKESDAS) 2013, prevalensi balita pendek juga mengalami peningkatan dibandingkan tahun sebelumnya, $2010(35,6 \%)$ dan 2007 (36,8\%). Selain itu, prevalensi balita pendek di Indonesia relatif tertinggi dibandingkan negara-negara tetangga seperti Malaysia (17\%), Myanmar (35\%), Vietnam (23\%), dan Thailand (16\%).

Berdasarkan Riset Kesehatan Dasar (RISKESDAS) 2013, prevalensi balita pendek di Jawa Barat sebesar 35,3\% terdiri dari 16,9\% sangat pendek dan 18,4\% pendek. Angka tersebut berada dibawah angka nasional $(37,2 \%)$. Namun terdapat dua belas kabupaten di Jawa Barat yang melampaui angka nasional. Kabupaten Sumedang, tempat peneliti melakukan masa studi, juga termasuk dalam 12 kabupaten tersebut.

Permasalahan balita pendek disebabkan oleh berbagai faktor, penelitian sebelumnya menyebutkan faktor utama yang menyebabkan balita pendek yaitu asupan ASI (air susu ibu) dan asupan pelengkap yang tidak optimal, infeksi berulang, dan kekurangan zat gizi mikro. ${ }^{3,4}$ Selain itu juga terdapat faktor lain seperti berat bayi lahir rendah, rendahnya pendapatan orang tua, dan usia kehamilan. Berdasarkan faktor diatas, asupan ASI dan makanan pendamping ASI (MP-
ASI) merupakan salah satu faktor yang dapat diperbaiki terutama dalam dua tahun pertama kelahiran. Tujuan penelitian ini adalah untuk mengetahui hubungan pemberian ASI eksklusif dan MP-ASI terhadap kejadian balita pendek usia 2 s.d. 5 tahun di Kecamatan Jatinangor.

\section{Metode}

Penelitian ini adalah penelitian analitik observasional yang dilakukan dengan pendekatan potong lintang. Subjek penelitian adalah anak balita berusia 2 sampai 5 tahun di Kecamatan Jatinangor. Besar sampel diketahui dengan menggunakan rumus analitik kategorik yaitu ukuran sampel minimum sebesar 63. Kriteria inklusi adalah balita yang memiliki riwayat lahir dengan berat lahir dan usia kehamilan normal, dan dapat dilakukan eksklusi apabila adanya keterbatasan dalam komunikasi, gangguan mental dan fisik, tidak tinggal menetap, tidak bersedia dilakukan wawancara, dan tinggi ibu balita dibawah $150 \mathrm{~cm}$. Penentuan sampel yang dilakukan dalam penelitian ini adalah sampling acak bertahap. Tahap pertama adalah memilih desa di Kecamatan Jatinangor. Kemudian, desa terpilih adalah Desa Cipacing dan Desa Hegarmanah. Tahap kedua, dipilih beberapa RW dari desa yang terpilih. Tahap selanjutnya adalah pengambilan sampel dilakukan pada sampel yang hadir di posyandu pada hari peneliti datang.

Penelitian ini dilakukan di Kecamatan Jatinangor pada bulan Juni-Agustus 2017. Sebelum dilakukan pengambilan data di Posyandu, aspek legalitas tetap diperhatikan dengan adanya pembuatan surat etik sesuai dengan Komite Etik Fakultas Kedokteran Universitas Padjadjaran nomor 728/UN6.C10/ PN/2017, surat izin penelitian dengan Puskesmas Kecamatan Jatinangor, Badan Perencanaan Pembangunan Penelitian dan Pengembangan Daerah (BAPPPPEDA) Kabupaten Sumedang, dan Dinas Kesehatan Kabupaten Sumedang.

Data yang diambil pada penelitian ini adalah data primer. Pertama dilakukan adalah pengambilan data usia, jenis kelamin, dan tinggi badan balita. Kemudian dilakukan wawancara kepada ibu balita mengenai ASI eksklusif dan makanan pendamping ASI. Wawancara dilakukan menggunakan kuesioner mengenai ASI eksklusif dan makanan pendamping ASI (MP-ASI) yang telah tervalidasi. Proses wawancara dilakukan peneliti dan orang yang telah diberikan pelatihan wawancara oleh peneliti utama. Analisis data menggunakan Uji statistik Chi square untuk data berdistribusi normal dan Uji Fisher untuk data yang tidak berdistribusi normal untuk mengetahui 
signifikasi hubungan antar variabel.

Data pengukuran usia, jenis kelamin, dan tinggi badan balita yang terkumpul dianalisis dengan merujuk pada ketentuan WHO yaitu menghitung Z-Score atau menggunakan grafik pertumbuhan rujukan WHO sesuai SK Menkes RI No. 1995/Menkes/SK/XII/2012. ${ }^{5}$ Berdasarkan $Z$-Score yang diperoleh dapat ditentukan status gizi seorang anak menurut tinggi badan per usia (TB/U) dengan klasifikasi yaitu sangat pendek apabila kurang dari -3 , pendek apabila lebih dari -3 sampai dengan kurang dari -2 , dan normal apabila lebih dari -2 sampai dengan lebih dari 2. Klasifikasi sangat pendek dan pendek digabungkan menjadi pendek ketika menganalisis hubungan antara pemberian ASI eksklusif dan MP-ASI dengan balita pendek.

Hasil wawancara mengenai pemberian ASI eksklusif disimpulkan berdasarkan pola menyusui ibu dari 0 s.d. 6 bulan. Klasifikasi pola menyusui berdasarkan definisi WHO yaitu menyusui eksklusif, menyusui predominan, dan menyusui parsial. Menyusui eksklusif adalah tidak memberi bayi makanan atau minuman lain, termasuk air putih, selain menyusui, kecuali obatobatan dan vitamin atau mineral tetes; ASI perah juga diperbolehkan. Menyusui predominan adalah menyusui bayi tetapi pernah memberikan sedikit air atau minum berbasis air misalnya teh, sebagai makanan atau minuman prelakteal sebelum ASI keluar. Menyusui parsial adalah menyusui bayi serta diberikan makanan buatan selain ASI, baik susu formula, bubur atau makanan lainnya sebelum bayi berusia enam bulan, baik diberikan secara kontinyu maupun diberikan sebagai makanan prelakteal. Klasifikasi ASI parsial dan predominan ASI digabungkan menjadi non ASI eksklusif ketika menganalisis hubungan antara pemberian ASI eksklusif dan balita pendek.

Hasil wawancara mengenai makanan pendamping ASI (MP-ASI) dikategorikan berdasarkan jenis MP-ASI menjadi dua yaitu buatan sendiri dan pabrik. Jenis MP-ASI terbagi atas tiga kelompok usia waktu pemberian MP-ASI yaitu usia 6 s.d. 9 bulan, 9 s.d 12 bulan, dan 12 s.d. 24 bulan. Pengkategorian dilakukan berdasarkan Pedoman Gizi Seimbang Kementerian Kesehatan RI 2014.

\section{Hasil}

Pada penelitian ini dilakukan pengambilan data berjumlah 92 balita; balita yang memenuhi kriteria inklusi untuk dijadikan sampel berjumlah 65 balita. Balita yang tidak memenuhi kriteria inklusi seperti memiliki riwayat berat lahir rendah dan lahir dengan usia kehamilan kurang (prematur) berjumlah 27 balita.

Tabel 1 menunjukkan bahwa usia ibu ketika melahirkan terbanyak usia 20-35 tahun, paling banyak ibu rumah tangga, atau tidak berkerja, dan paling banyak tamat SMA, sedangkan pekerjaan ayah terutama wiraswasta atau pedagang. Angka kejadian balita pendek pada penelitian ini sebesar $40 \%$ yang terdiri atas pendek dan sangat pendek.

Tabel 1 Distribusi karakteristik orang tua dan anak balita

\begin{tabular}{lcc}
\hline \multicolumn{1}{c}{ Karakteristik } & Jumlah (n) & Persentase (\%) \\
\hline Usia ibu ketika melahirkan & 7 & 9,6 \\
$<20$ tahun & 51 & 69,9 \\
$20-35$ tahun & 15 & 20,5 \\
$>35$ tahun & & 1,5 \\
Pekerjaan ayah & 1 & 21,5 \\
$\quad$ Tidak bekerja & 14 & 1,5 \\
Buruh tani/buruh lainnya & 1 & 1,5 \\
PNS & 1 & 47,7 \\
TNI/Polisi & 31 & 26,2 \\
Wiraswasta/pedagang & 17 & 41,5 \\
Swasta & & 58,5 \\
Pendidikan terakhir ibu & 27 & 75,4
\end{tabular}


Bekerja

Kelompok usia balita

24-35 bulan

36-47 bulan

48-59 bulan

Jenis kelamin

Perempuan

Laki-laki

Status gizi berdasarkan $\mathrm{TB} / \mathrm{U}$

Sangat pendek

$13 \quad 20,0$

Pendek

Normal

39

60,0

Tabel 2 Distribusi karakteristik pemberian ASI

\begin{tabular}{lcc}
\hline \multicolumn{1}{c}{ Karakteristik } & Jumlah (n) & Persentase (\%) \\
\hline Pemberian ASI eksklusif & 36 & 50,8 \\
ASI parsial & 7 & 10,8 \\
Predominant ASI & 22 & 38,5 \\
ASI eksklusif & & 15,4 \\
Lama waktu pemberian ASI & 10 & 3,1 \\
0-6 bulan & 2 & 7,7 \\
7-9 bulan & 5 & 49,2 \\
10-12 bulan & 32 & 24,6 \\
13-24 bulan & 32 & \\
$>2$ tahun & 16 & \\
\hline
\end{tabular}

Tabel 3 Hubungan pemberian ASI eksklusif dengan balita pendek

\begin{tabular}{|c|c|c|c|c|c|c|}
\hline \multirow{2}{*}{$\begin{array}{l}\text { Pemberian } \\
\text { ASI eksklusif }\end{array}$} & \multicolumn{2}{|c|}{ Status gizi berdasarkan $\mathrm{PB} / \mathrm{U}$} & \multirow[b]{2}{*}{ Total } & \multirow[b]{2}{*}{$\mathbf{P}^{*}$} & \multirow[b]{2}{*}{ OR } & \multirow[b]{2}{*}{$95 \% \mathrm{CI}$} \\
\hline & $\begin{array}{c}\text { Pendek } \\
\text { n\% }\end{array}$ & $\begin{array}{c}\text { Normal } \\
\mathbf{n} \%\end{array}$ & & & & \\
\hline ASI eksklusif & $14(63,6 \%)$ & $8(36,4 \%)$ & $22(100 \%)$ & 0,012 & 4,521 & $1,513-13,511$ \\
\hline Non ASI eksklusif & $12(27,9 \%)$ & $31(72,1 \%)$ & $43(100 \%)$ & & & \\
\hline
\end{tabular}

Tabel 2 menunjukkan pola menyusui paling banyak adalah ASI parsial. Selain itu didapatkan lama waktu pemberian ASI paling banyak yaitu rentan 13-24 bulan.

Tabel 3 menunjukkan bahwa hasil uji statistik Chi-square terdapat hubungan signifikan antara pemberian ASI eksklusif dan balita pendek. Hasil analisis diperoleh pula OR $=4,521$ artinya anak yang pola menyusui ASI eksklusif mempunyai peluang 4,521 kali menjadi pendek dibandingkan non ASI eksklusif.
Tabel 4 menunjukkan waktu pertama pemberian MP-ASI paling banyak ketika usia 6 bulan. Jenis pemberian MP-ASI umumnya diberikan dari pabrik (usia 6 s.d. 9) dan buatan sendiri (usia 9 s.d 24 bulan). Pada usia 12 s.d. 24 bulan, seluruh balita diberikan jenis MP-ASI dari buatan sendiri. 
Yogi Subandra Dwitama : Hubungan pemberian ASI Eksklusif dan Makanan Pendamping ASI terhadap Balita Pendek Usia 2 sampai 5 tahun di Kecamatan Jatinangor

Tabel 4 Distribusi karakteristik pemberian MP-ASI

\begin{tabular}{lcc}
\hline \multicolumn{1}{c}{ Karakteristik } & Jumlah (n) & Persentase (\%) \\
\hline Usia pemberian MP- ASI pertama & 13 & 20,0 \\
$<6$ bulan & 32 & 49,2 \\
6 bulan & 20 & 30,8 \\
$>6$ bulan & & \\
Usia 6 s.d. 9 bulan & & 78,5 \\
Jenis MP-ASI & 51 & 21,5 \\
$\quad$ Pabrik & 14 & \\
$\quad$ Buatan sendiri & & 87,7 \\
Usia 9 s.d. 12 bulan & & 12,3 \\
Jenis MP-ASI usia 9 s.d. 12 bulan & 57 & \\
$\quad$ Buatan sendiri & 8 & 100 \\
Pabrik & & \\
Usia 12 s.d. 24 bulan \\
Jenis MP-ASI usia 12 s.d. 24 bulan \\
$\quad$ Buatan sendiri
\end{tabular}

Tabel 5 Hubungan pemberian MP-ASI terhadap balita pendek

\begin{tabular}{|c|c|c|c|c|c|c|}
\hline \multirow{2}{*}{$\begin{array}{c}\text { Pola pemberian } \\
\text { MP-ASI }\end{array}$} & \multicolumn{2}{|c|}{ Status gizi berdasarkan $\mathrm{PB} / \mathrm{U}$} & \multirow[b]{2}{*}{ Total } & \multirow[b]{2}{*}{$\mathbf{P}$} & \multirow[b]{2}{*}{ OR } & \multirow[b]{2}{*}{$95 \%$ CI } \\
\hline & $\begin{array}{c}\text { Pendek } \\
\text { n\% }\end{array}$ & $\begin{array}{c}\text { Normal } \\
\text { n\% }\end{array}$ & & & & \\
\hline \multicolumn{7}{|c|}{ Usia 6 s.d. 9 bulan } \\
\hline \multicolumn{7}{|l|}{ Jenis MP-ASI } \\
\hline Buatan sendiri & $6(42,9 \%)$ & $8(57,1 \%)$ & $40(100 \%)$ & 1,000 & 1,163 & \multirow{2}{*}{$0,351-3,854$} \\
\hline Pabrik & $20(39,2 \%)$ & $31(60,8 \%)$ & $25(100 \%)$ & & & \\
\hline \multicolumn{7}{|c|}{ Usia 9 s.d. 12 bulan } \\
\hline \multicolumn{7}{|l|}{ Jenis MP-ASI* } \\
\hline Buatan sendiri & $24(41,9 \%)$ & $33(57,9 \%)$ & $57(100 \%)$ & 0,301 & & \\
\hline Pabrik & $2(25,0 \%)$ & $6(75,0 \%)$ & $8(100 \%)$ & & & \\
\hline
\end{tabular}

Tabel 5 menunjukkan bahwa hasil uji statistik Chi-square. Keseluruhan kelompok usia pemberian jenis MP-ASI tidak terdapat hubungan signifikan antara pemberian MP-ASI dengan balita pendek. Pada usia 12 s.d. 24 bulan tidak dapat dilakukan analisis karena keseluruhan balita diberikan jenis MP-ASI dari buatan sendiri.

\section{Pembahasan}

Penelitian ini dilakukan pada 65 balita di Kecamatan Jatinangor. Anak balita berjenis kelamin laki-laki sebanyak 34 orang dan perempuan sebanyak 31 orang. Balita yang dipilih adalah balita yang memiliki riwayat lahir dengan berat lahir dan usia kehamilan normal karena peneliti ingin mengontrol variabel perancu. Pemberian ASI eksklusif dan makanan pendamping ASI (MP-ASI) dinilai dari lahir hingga berusia 2 tahun karena usia tersebut merupakan waktu pertumbuhan paling cepat dan periode paling kritis pada pertumbuhan tinggi badan. ${ }^{1,6}$

Dari 65 balita yang diambil, didapatkan kejadian balita pendek sebanyak $26(40,0 \%)$ 
balita yaitu 13 (20\%) pendek dan $13(20,0 \%)$ sangat pendek. Menurut WHO, prevalensi pendek lebih dari $20 \%$ dapat digolongkan menjadi permasalahan kesehatan. Pada penelitian ini, jumlah kejadian balita pendek sebanyak 40,0\% maka balita pendek di Jatinangor dapat digolongkan menjadi permasalahan kesehatan.

Hasil dari analisis data menunjukkan bahwa terdapat hubungan antara pemberian ASI eksklusif dengan pendek di Kecamatan Jatinangor dengan OR sebesar 4,521. Dapat dikatakan anak yang pola menyusui ASI eksklusif lebih berpeluang menjadi pendek dibandingkan anak yang pola menyusui non ASI eksklusif. Hal ini berbeda dengan rekomendasi WHO yaitu anak hanya diberikan ASI (ASI eksklusif). Hasil penelitian ini juga berbeda dengan penelitian yang dilakukan Nadhiroh di Surabaya tahun 2015 dan Kuchenbecker di Malawi tahun 2015 yaitu anak yang pola menyusui non ASI eksklusif mempunyai peluang lebih tinggi menjadi pendek dibandingkan ASI eksklusif. ${ }^{7,8}$

Perbedaan ini mungkin disebabkan oleh faktor lain yaitu jumlah ASI yang diberikan dan asupan gizi ibu menyusui yang memengaruhi ASI eksklusif. Hal tersebut didukung pada penelitian Nizkiniaz di Iran mengatakan bahwa asupan gizi ibu menyusui berhubungan dengan komposisi ASI. ${ }^{9}$ Selain itu juga terdapat faktor lain yang perlu dipertimbangkan yaitu riwayat infeksi berulang seperti diare, infeksi saluran pernafasan atas, dan infeksi lainnya memengaruhi pertumbuhan tinggi balita. ${ }^{10}$

Tidak terdapat hubungan yang signifikan antara jenis pemberian MP-ASI dan balita pendek. MP-ASI dengan kejadian balita pendek memiliki nilai $p>0,05$ atau dapat dikatakan tidak memiliki hubungan yang signifikan terhadap dengan balita pendek. Hal ini berbeda dengan penelitian sebelumnya oleh Kumar mengatakan bahwa ada hubungan pemberian makanan pendamping ASI terhadap pendek. ${ }^{11}$ Perbedaan ini disebabkan oleh faktor lain yaitu kekurangan zat mikro seperti vitamin A dan zink. Bentuk vitamin A tersebut, yang mengontrol pertumbuhan khususnya pertumbuhan jaringan skeletal adalah asam retinoat. ${ }^{12}$ Menurut Cunane, zink memengaruhi aktivitas hormon pertumbuhan manusia. Pada anak anak yang mengalami defisiensi vitamin A dan zink berpengaruh terhadap proses pertumbuhan linier. ${ }^{13}$

Selain faktor faktor yang disebutkan diatas, adapun faktor faktor yang dapat memengaruhi status gizi balita yaitu kondisi sosial ekonomi. Banyak penelitian menunjukkan terjadi peningkatan kasus kurang gizi disebabkan kondisi ekonomi keluarga. Bukan hanya itu, pendidikan ibu, pekerjaan ibu, pendapatan keluarga, jumlah anak, pola asuh, dan riwayat penyakit infeksi juga mempengaruhi pertumbuhan anak balita. ${ }^{14}$ Pada penelitian ini, pekerjaan ayah dominan wiraswasta/pedagang maka dapat diperkirakan pendapatan keluarga rendah, sehingga akan berpengaruh terhadap pemilihan bahan makanan dan akan mempengaruhi pertumbuhan balita.

Keterbatasan dalam penelitian ini yaitu peneliti kurang memperhitungkan faktor lain seperti jumlah ASI yang diberikan, kandungan gizi pada ASI ibu, status gizi ibu, riwayat infeksi, kondisi sosial ekonomi, dan sulitnya ibu untuk mengingat makanan yang diberikan kepada anak beberapa tahun sebelumnya. Selain itu, di Jatinangor masih memiliki proporsi berat lahir rendah dan kelahiran prematur cukup tinggi yang membuat peneliti harus mencari lebih banyak responden.

Berdasarkan hasil penelitian ini dapat disimpulkan bahwa terdapat hubungan antara pemberian ASI eksklusif dan balita pendek tetapi tidak terdapat hubungan antara makanan pendamping ASI (MP-ASI) dan balita pendek di Kecamatan Jatinangor. Perlu diadakan penelitian selanjutnya untuk mengetahui faktor faktor yang mempengaruhi balita pendek di Jatinangor dengan memperhatikan faktor-faktor lain seperti asupan gizi ibu menyusui, status gizi ibu, riwayat infeksi, status sosial ekonomi, dan asupan mikronutrien seperti vitamin A dan zink. Diharapkan penelitian selanjutnya dapat menemukan faktor utama yang menyebabkan balita pendek di Jatinangor. Dinas Kesehatan Kabupaten Sumedang harus memberikan perhatian khusus dikarenakan angka kejadian balita pendek di Jatinangor tergolong permasalahan kesehatan. Menurut WHO, rekomendasi dalam 180 hari pertama anak hanya diberikan ASI eksklusif. ${ }^{15}$ Namun pada penelitian ini, kualitas ASI meningkatkan risiko balita pendek yang mungkin disebabkan oleh faktor lain seperti asupan gizi dan status gizi ibu. Disarankan bagi ibu yang sedang menyusui untuk meningkatkan asupan gizi dan status gizi. Selain itu, perlu intervensi berupa edukasi mengenai pencegahan terhadap faktor-faktor yang dapat menyebabkan pendek pada balita.

\section{Daftar Pustaka}

1. Countries M, Martorell R, Horta BL, Adair LS, Stein AD, Richter L, et al. Weight Gain in the First Two Years of Life Is an Important Predictor of Schooling Outcomes in Pooled Analyses from Five Birth Cohorts from. 2010;

2. Heryanah H, Pusat Statistik Kota Sukabumi B. Ageing Population dan Bonus Demografi Kedua di Indonesia. Populasi. 2015;23:1-16. 
3. Black RE, Victora CG, Walker SP, Bhutta ZA, Christian P, De Onis M, et al. Maternal and child undernutrition and overweight in low-income and middle-income countries. Lancet. 2013;382(9890):427-51.

4. Dewey KG, Mayers DR. Early child growth: How do nutrition and infection interact? Matern Child Nutr. 2011;7(SUPPL. 3):12942.

5. Menteri Kesehatan Republik Indonesia. Peraturan Menteri Kesehatan No 1995 tahun 2010 Tentang Standar Pengukuran Antropometri Bagi Penentuan Gizi Anak. Kementrian Kesehatan Republik Indonesia; 2010.

6. Dewey KG, Adu-Afarwuah S. Systematic review of the efficacy and effectiveness of complementary feeding interventions in developing countries. Matern Child Nutr. 2008 Apr;4 Suppl 1:24-85.

7. Kuchenbecker J, Jordan I, Reinbott A, Herrmann J, Jeremias T, Kennedy G, et al. Exclusive breastfeeding and its effect on growth of Malawian infants: results from a cross-sectional study. Vol. 35, Paediatrics and International Child Health. Suite 1C, Joseph's Well, Hanover Walk, Leeds LS3 1AB, UK; 2015. p. 14-23.

8. Rahayu NS, Nadhiroh K. Faktor Yang Berhubungan Dengan Kejadian Stunting Pada Balita. Media Gizi Indones. 2015;(Vol 10, No 1 (2015): Jurnal Media Gizi Indonesia):13-9.

9. Nikniaz L, Mahdavi R, Sr A, Khiabani S. Association Between Fat Content of Breast Milk and Maternal Nutritional Status and Infants 'Weight in Tabriz, Iran. 2009;15(1):37-44.
10. Checkley W, Buckley G, Gilman RH, Assis AMO, Guerrant RL, Valentiner-branth $P$, et al. Multi-country analysis of the effects of diarrhoea on childhood stunting. 2017;(September):816-30.

11. Kumar, Dinesh; K., N. Goel; C., Poonam Mittal; Misra P. Influence of Infant-feeding Practices on Nutritional Status of Under-five Children. Indian J Pediatr. 2006;417-8.

12. Taufiqurrahman T, Hadi H, Julia M, Herman S. Defisiensi Vitamin A Dan Zinc Sebagai faktor Risiko Terjadinya Stunting Pada Balita Di Nusa Tenggara Barat. Media Penelit dan Pengemb Kesehatan; 2009 Suplemen vol 19 Tahun 2009. 2012;

13. Adriani, Merryana; Wirjatmadi B. The effect of adding zinc to vitamin $A$ on IGF-1, bone age and lineargrowth in stunted children. $\mathrm{J}$ Trace Elem Med Biol. 2014;28(4):431-5.

14. Géa-Horta T, Felisbino-Mendes MS, Ortiz RJF, Velasquez-Melendez G. Association between maternal socioeconomic factors and nutritional outcomes in children under 5 years of age,. J Pediatr (Rio J). 2016;92:57480.

15. Kramer MS, Kakuma R. Optimal duration of exclusive breastfeeding. Cochrane database Syst Rev. 2002;554(1):CD003517. 